\title{
The biology of Hepatocellular carcinoma: implications for genomic and immune therapies
}

\author{
Galina Khemlina ${ }^{1,4^{*}}$, Sadakatsu Ikeda ${ }^{2,3}$ and Razelle Kurzrock ${ }^{2}$
}

\begin{abstract}
Hepatocellular carcinoma (HCC), the most common type of primary liver cancer, is a leading cause of cancer-related death worldwide. It is highly refractory to most systemic therapies. Recently, significant progress has been made in uncovering genomic alterations in HCC, including potentially targetable aberrations. The most common molecular anomalies in this malignancy are mutations in the TERT promoter, TP53, CTNNB1, AXIN1, ARID1A, CDKN2A and CCND1 genes. PTEN loss at the protein level is also frequent. Genomic portfolios stratify by risk factors as follows: (i) CTNNB1 with alcoholic cirrhosis; and (ii) TP53 with hepatitis B virus-induced cirrhosis. Activating mutations in CTNNB1 and inactivating mutations in AXIN1 both activate WNT signaling. Alterations in this pathway, as well as in TP53 and the cell cycle machinery, and in the PI3K/Akt/mTor axis (the latter activated in the presence of PTEN loss), as well as aberrant angiogenesis and epigenetic anomalies, appear to be major events in HCC. Many of these abnormalities may be pharmacologically tractable. Immunotherapy with checkpoint inhibitors is also emerging as an important treatment option. Indeed, 82\% of patients express PD-L1 (immunohistochemistry) and response rates to anti-PD-1 treatment are about 19\%, and include about 5\% complete remissions as well as durable benefit in some patients. Biomarker-matched trials are still limited in this disease, and many of the genomic alterations in HCC remain challenging to target. Future studies may require combination regimens that include both immunotherapies and molecularly matched targeted treatments.
\end{abstract}

Keywords: Hepatocellular carcinoma, Next-generation sequencing, Molecular targeted therapyg

\section{Background}

Malignant tumors of the liver are classified as primary or secondary (metastatic) [1]. Common primary malignancies of the liver are hepatocellular carcinomas (HCC), which represent approximately $90 \%$ of cases [2]. Cholangiocarcinoma is a bile duct neoplasm accounting for $10 \%-15 \%$ of primary hepatic malignancies [3]. The nosology of bile duct cancer includes the following: (i) intrahepatic cholangiocarcinoma (ICC), arising from the small bile ducts within the liver; (ii) extra-hepatic cholangiocarcinoma (ECC), originating from the extra-hepatic bile duct epithelium; and (iii) gallbladder cancer [4]. Fibrolamellar carcinoma is a rare primary liver tumor that represents only $0.85 \%$ of primary

\footnotetext{
* Correspondence: gkhemlina@ucsd.edu

${ }^{1}$ Department of Geriatrics, University of California, UC San Diego, 9500

Gilman Drive, \#9111, La Jolla, CA 92093-9111, USA

${ }^{4}$ Kaiser Permanente Southern California, San Diego, USA

Full list of author information is available at the end of the article
}

liver cancers, but is the diagnosis in $13.4 \%$ of young patients (under the age of 40) [5].

HCC is a major global health problem. From a worldwide perspective, it is the third most common cause of cancerrelated mortality [6]. HCC has several known etiologic factors: hepatitis $\mathrm{B}$, hepatitis $\mathrm{C}$, alcohol use, non-alcoholic steatohepatitis, and obesity $[7,8]$. The exception is fibrolamellar carcinoma, which is generally found in adolescents and young adults who have no underlying liver disease [9]. The risk factors for fibrolamellar carcinoma remain unknown [10]. Fibrolamellar carcinoma usually develops in a normal-appearing, non-cirrhotic liver. Patients diagnosed with fibrolamellar carcinoma have a better outcome than those with other forms of HCC [10]. Recent molecular research have shown a high prevalence of a fusion geneDNAJB1-PRKACA (found in 79\%-100\% of patients diagnosed with fibrolamellar carcinoma) [10]. In addition, fibrolamellar carcinoma demonstrates strong expression of 
EGFR by immunohistochemistry $[9,11]$. Various genomic features characterize the stages of the diverse types of HCC. (Table 1).

For patients suffering from advanced, conventional HCC, chemotherapy failed to demonstrate a survival advantage [12]. The multikinase inhibitor sorafenib is the only agent that was approved by the Food and Drug Administration (FDA) for HCC [13]. It demonstrated a statistically significant, but modest, survival benefit in two large phase III trials $[12,14,15]$. The most frequent toxicities related to sorafenib are fatigue, nausea, weight loss, hand-foot skin reaction and rash, and diarrhea [16]. However, the prognosis for patients remains dismal because the response rate with sorafenib is less than $5 \%$ [15] and the median overall survival is extended by only about 2.5 months [15]. There is no established, effective second-line drug beyond sorafenib. Hence, understanding the underlying biology of HCC and the development of innovative treatments for this malignancy is of paramount clinical importance [17].

\section{Genomic aberrations in HCC}

We reviewed the genomic landscape for primary $\mathrm{HCC}$ (other than cholangiocarcinoma and fibrolamellar carcinoma) and implications for therapy. Interestingly, recent genomic sequencing identified 161 putative genetic alterations in HCC [18] (Table 2).

Assessment of genomic portfolios defined three groups of genes related to risk factors as follows: (i) CTNNB1 with alcoholico; (ii) TP53 with hepatitis B virus (HBV) induced cirrhosis; and (iii) others that do not have a distinct pattern, mainly in patients with hepatitis $\mathrm{C}$ virus (HCV) infection, metabolic syndrome, and hemochromatosis [18]. Analyses according to tumor stage demonstrated that TERT promoter mutation was seen more frequently in early-stage tumors. On the other hand, TP53 and CDKN2A alterations, as well as amplification of the chromosome 11 amplicon that encodes FGF3, FGF4, FGF19 and/or CCND1 were observed more commonly in advanced stages [18].

\section{Signaling pathways}

Recent data have identified several abnormal signaling pathways in liver carcinogenesis. Some of these aberrant signals provide a potential source of novel molecular targets for new therapies [19].

\section{Wnt pathway}

\section{CTNNB1}

Approximately $11-41 \%$ of liver malignancies harbor CTNNB1-activating mutations [20-22]. The beta-catenin protein CTNNB1 is an important component of the canonical Wnt signaling pathway [23]. The encoded protein product anchors the actin cytoskeleton and may be responsible for communicating the contact inhibition signal that causes cells to halt division once the epithelial sheet is complete [23]. Delgado and coworkers demonstrated a complete response in a mouse model of hepatic carcinogenesis after suppression of $\beta$-catenin [24]. Several other inhibitors of this pathway, in particular WNT inhibitors, are also being tested in clinical studies, and include, but are not limited to, PRI-724 (NCT02195440) and BBI608 (NCT02279719). Further, accumulated evidence suggests that non-steroidal anti-inflammatory drugs (NSAIDs) such as celecoxib and sulindac also impact the Wnt/ $\beta$ catenin signaling pathway in human cancer cells [25]. Finally, gamma secretase inhibitors and sorafenib may also target activated CTNNB1 or Wnt pathways [26-28]. Gamma-secretase cleaves intracellular Notch, resulting in Notch activation; gamma secretase inhibitors can be effective at controlling disease growth in desmoid tumors, the vast majority of which have CTNNB1 mutations [26]. Sorafenib may also decrease CTNNB1 class-specific, Wnt-pathway activation $[27,28]$.

\section{AXIN1}

Approximately $5-19 \%$ of liver cancer specimens harbor AXIN1 mutations [20-22]. AXINI, by controlling the level of $\beta$-catenin, serves as a negative regulator of $\mathrm{Wnt} / \beta$-catenin signaling [29]. Overexpression of wild-type AXIN1, but not mutant $A X I N 1$, suppressed the proliferation of HCC cell lines and accelerated their programmed cell death, implicating AXIN1 as a therapeutic target in HCC [29]. Supporting this concept is the observation that expression of the wild-type AXIN1 gene by adenovirus-mediated gene transfer promoted apoptosis in HCC cells, which had accumulated $\beta$-catenin as result of $A P C, A X I N 1$, or CTNNB1 gene mutations [30]. AXIN stabilization by suppressing the poly-ADP-ribosylating enzymes tankyrase 1 and tankyrase 2 with the small molecule inhibitor XAV939 has been suggested as a novel way to target the Wnt pathway [31]. Finally, non-steroidal anti-inflammatory agents may inhibit the Wnt/ $\beta$-catenin signaling pathway in human cancer cells [25].

\section{P53 pathway \\ TP53}

Approximately $13-48 \%$ of liver cancers harbor TP53 mutations [20-22]. TP53 acts as a tumor suppressor in tumors; it induces growth arrest or apoptosis depending on the physiological settings and cell type [23]. Genomic aberrations in the p53 pathway are the most frequent abnormalities in diverse cancers and often correlate with high-grade histology [22]. TP53 mutations in HCC in afflicted patients in Western countries are also linked with worse clinical stage and prognosis [21]. The TP53 gene regulates multiple biologic processes, including the expression of VEGF-A [32]. Of importance in this regard, anti-angiogenic agents, such as bevacizumab, were associated with improved progression-free survival 
Table 1 Pathologic features and molecular signatures of liver lesions

\begin{tabular}{ll}
\hline Tumor type & Pathologic features \\
\hline $\begin{array}{l}\text { Focal nodular } \\
\text { hyperplasia } \\
\text { (FNH) }\end{array}$ & $\begin{array}{l}\text { Well-differentiated } \\
\text { hepatocytes [88] }\end{array}$ \\
& $\begin{array}{l}\text { Intervening fibrous bands } \\
\text { radiating from a central } \\
\text { scar, Abundant, } \\
\text { proliferating bile ductules }\end{array}$ \\
& $\begin{array}{l}\text { Well differentiated } \\
\text { Hepatocellular }\end{array}$ \\
$\begin{array}{l}\text { Adenoma } \\
\text { (HCA) }\end{array}$ & $\begin{array}{l}\text { in cords one to two cells } \\
\text { thick and lacking portal }\end{array}$ \\
& tracts [88] \\
& Rare bile ductules
\end{tabular}

Naked arterioles

Dysplastic nodules (DN)
Vaguely (low-grade DN) or distinctly (high-grade DN) nodular with peripheral fibrous scar [96]

Mild increase in cell density with monotonous pattern, with no cytologic atypia (low-grade DN) or increased cellularity in irregular trabecular pattern with moderate atypia (high-grade DN)

No pseudoglands or markedly thickened trabeculae

Unpaired arteries sometimes present

No stromal invasion

Increased cell density with an elevated nuclear/ cytoplasm ratio and irregular thin-trabecular pattern [98]

Varying numbers of portal tracts inside the nodule

Pseudo-glandular pattern

Diffuse fatty change

Varying numbers of unpaired arteries

Stromal invasion present
Table 1 Pathologic features and molecular signatures of liver lesions (Continued)

\begin{tabular}{|c|c|c|}
\hline \multirow[t]{2}{*}{$\begin{array}{l}\text { Fibrolamellar } \\
\text { HCC }\end{array}$} & $\begin{array}{l}\text { Arising in non-cirrhotic } \\
\text { liver [11] }\end{array}$ & $\begin{array}{l}\text { Fusion gene-DNAJB1- } \\
\text { PRKACA [10] }\end{array}$ \\
\hline & $\begin{array}{l}\text { Nests of well-differentiated } \\
\text { oncocytic cells in a back- } \\
\text { ground of acellular but } \\
\text { dense collagen bundles ar- } \\
\text { ranged in parallel lamellae }\end{array}$ & $\begin{array}{l}\text { Overexpression of } \\
\text { EGFR [11]. }\end{array}$ \\
\hline \multirow[t]{6}{*}{$\begin{array}{l}\text { Advanced } \\
\text { HCC }\end{array}$} & $\begin{array}{l}\text { Unifocal, multifocal, or } \\
\text { diffusely infiltrative soft } \\
\text { tumor [98] }\end{array}$ & $\begin{array}{l}\text { Inactivation of TP53 } \\
{[108,109]}\end{array}$ \\
\hline & $\begin{array}{l}\text { Polygonal cells with } \\
\text { distinct cell membranes, } \\
\text { abundant granular } \\
\text { eosinophilic cytoplasm, } \\
\text { round nuclei with course } \\
\text { chromatin, and higher } \\
\text { nucleus/cytoplasm ratio, }\end{array}$ & \\
\hline & Tumor capsule present & $\begin{array}{l}\text { Activating mutations } \\
\text { of CTNNB1 [108] }\end{array}$ \\
\hline & $\begin{array}{l}\text { Invasion and minute } \\
\text { intrahepatic metastasis }\end{array}$ & $\begin{array}{l}\text { Other alterations listed } \\
\text { in Table } 2\end{array}$ \\
\hline & Unpaired arteries & \\
\hline & Absent portal tracts & \\
\hline
\end{tabular}

Abbreviations: APC Adenomatous Polyposis Coli, CSN5 COP9 Signalosome complex (CSN), CRP C reactive protein, DN Dysplastic nodules, DNAJB1-PRKACA(DnaJ (Hsp40) Homolog, Subfamily B, Member 1- Protein Kinase, CAMP-Dependent, Catalytic, Alpha), CTNNB1 Catenin Beta 1, EGFR Epidermal Growth Factor Receptor, EpCAM The epithelial cell adhesion molecule, GS Glutamine synthetase, HCA Hepatocellular adenomas, HNF1 Hepatocyte Nuclear Factor 1, HPCs Hepatic progenitor cells, HSP70 Heat-shock protein70, GPC3 Encodes glypican-3, IHC Immunohistochemistry, LYVE1 Lymphatic Vessel Endothelial Hyaluronic Acid Receptor 1, NCAM Neural Cell Adhesion Molecule, SAA Serum amyloid A, TCF1 Transcription Factor 1, TERT Telomerase reverse transcriptase

(PFS) in patients whose tumors harbored TP53 mutations [33, 34]. In addition, it has been postulated that malignances with TP53 mutations may be sensitive to Wee1 inhibitors, which are in clinical trials [35, 36].

\section{Chromatin remodeling ARID1A}

Approximately $4-17 \%$ of HCCs harbor ARID1A alterations [20-22, 37]. ARID1A participates in transcriptional activation and repression of select genes by chromatin remodeling [23]. ARID1A alterations were significantly more common in HCC related to alcohol abuse than in tumors of other etiology and demonstrated a correlation with CTNNB1 mutations [20]. Samartzis and co-investigators reported that PI3K/AKT-pathway activation is also a crucial mechanism in ARID1A-mutated cancers and, consequently, ARID1A-deficient tumors show preclinical sensitivity to treatment with PI3K/Akt/mTor pathway inhibitors [38].

TERT promoter mutations in $61 \%$ of early HCC [97]

ARID2

Approximately $5 \%$ to $7 \%$ of liver cancers harbor ARID2 mutations [18, 21, 37]. ARID2 is implicated in transcriptional activation and suppression of select genes by 
Table 2 Commonly aberrant genes in hepatocellular carcinoma

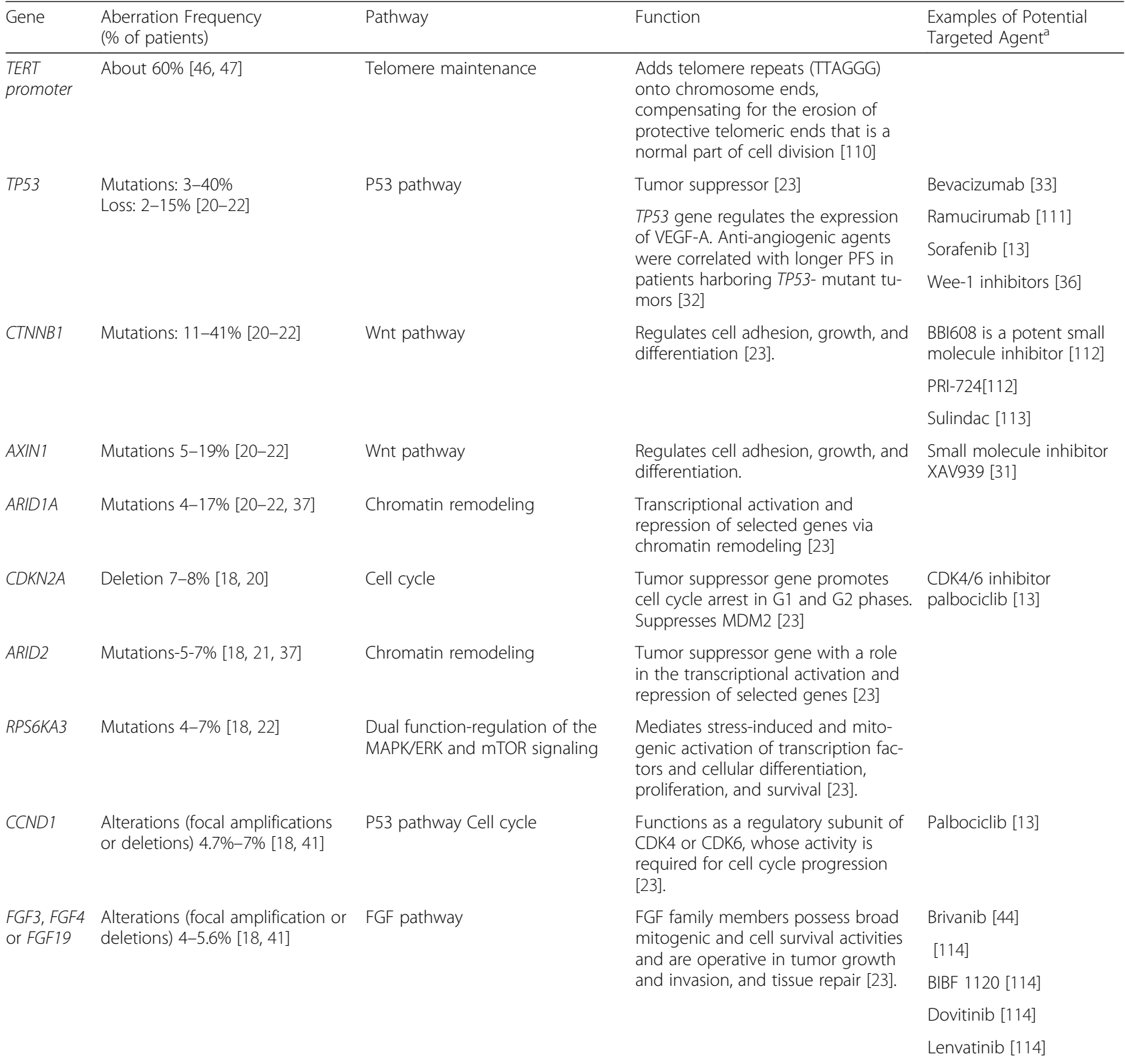

${ }^{\mathrm{a}}$ For many of these targeted agents, it is not yet clear if use of the agent in patients with the cognate aberrant genes is effective

chromatin remodeling [23]. ARID2 is an important tumor suppressor gene, but targeting it is challenging [39]. ARID1A and ARID2 are components of the SWItch/Sucrose Non-Fermentable (SWI/SNF)-related chromatin remodeling complex. Better comprehension of the network of molecules involved in the SWI/SNF complex is required [40].

\section{Cell cycle}

CDKN2A

Approximately $8 \%$ of $\mathrm{HCCs}$ harbor $C D K N 2 A$ deletions $[18,20]$. CDKN2A is a tumor suppressor gene that induces cell cycle arrest in G1 and G2 phases; it also suppresses the oncogenic action of CDK4/6 and MDM2 [23]. In the presence of $C D K N 2 A$ mutations, CDK4 and CDK6 expression are up-regulated. $C D K N 2 A$ inactivation has been correlated with poor prognosis independently of other traditional factors; in addition, $C D K N 2 A$ alterations are discerned in more advanced, aggressive cancer [18]. Given the frequent loss of CDKN2A in HCC, CDK4/6 inhibitors are being tested in advanced HCC [13].

\section{CCND1, FGF3, FGF4 or FGF19}

Approximately $5 \%$ to $7 \%$ of liver cancer specimens harbor alterations of CCND1; $4 \%$ to $6 \%$ have alterations in FGF3, FGF4, or FGF19 genes [18, 41]. Amplification of 
FGF3/ FGF4/FGF19/CCND1 (all of which reside on the same amplicon on the long arm of chromosome 11) is associated with poor prognosis in resected HCCs, independent of classical prognostic variables [18]. Clonal growth and tumorigenicity of $\mathrm{HCC}$ cells harboring the 11q13.3 amplicon were selectively suppressed by an anti-FGF19 antibody as well as by RNAi-mediated knockdown of FGF19 or CCND1 [42]. It is plausible that $11 \mathrm{q} 13.3$ amplification is a biomarker for patients most likely to respond to anti-FGF/FGFR agents [42].

Lenvatinib, an oral tyrosine kinase inhibitor targeting FGFR1-4, VEGFR1-3, KIT RET, and PDGFR-beta, has induced partial responses in a small subgroup of patients with HCC [43]. Not unexpectedly, when given to unselected patients with HCC, the FGFR inhibitor brivanib did not improve survival [44]. Dovitinib (another FGFR inhibitor) was also not superior to sorafenib in unselected patients with advanced HCC [45]. These trials suggest that studies with patient selection for the presence of the target gene are needed.

\section{Other genomic alterations: TERT}

$T E R T$ promoter mutations were recently identified as the most frequent somatic genomic defect in HCC, with an overall frequency of $60 \%$ to $90 \%$ [46-48]. Telomerase is a ribonucleoprotein enzyme that is critical for the replication of chromosome termini in most eukaryotes [23]. Telomerase overexpression is a key component of the transformation process in many cancer cells [23]. TERT extends telomeres and TERT mutations activate this activity, allowing cells to continue dividing. TERT alterations are one of the earliest genomic anomalies involved in malignant transformation in HCC and may, therefore, be considered as a tumor "gatekeeper." [46] Tahtouh and colleagues demonstrated that telomerase inhibition decreases alpha fetoprotein (AFP) expression in individuals with $\mathrm{HCC}$ and may have a suppressive effect on cell growth via attenuation of telomere repair [49]. Unfortunately, low-dose cyclophosphamide administration followed by GV1001 vaccinations (GV1001 being a telomerase vaccine) did not demonstrate efficacy [50]. Several other approaches are being studied in the development of vaccines that may induce TERT immunogenicity [51]. Other telomerase-targeting compounds, such as small molecule inhibitors RHPS4 and BRACO-19, and also PARP inhibitors, which lead to a rapid decrease in median telomere length, are innovative strategies [51-53].

\section{RPS6KA3}

About 4\% to 7\% of liver cancer tissues bear RPS6KA3 mutations $[18,22]$. In part by modulating mTOR signaling, RPS6KA3 mediates stress-induced and mitogenic activation of transcription factors and cellular differentiation, growth, and survival [23]. In addition, RPS6KA3 (RSK2) is a kinase enzyme that acts downstream of the MAPK/ERK pathway [40]. RPS6KA3 tends to be altered in poorly differentiated HCC [54]. Taking into account its dual function (regulation of the MAPK/ERK and mTOR signaling), RPS6KA3 mutations may be difficult to target [40].

Other functions for RPS6KA3 may also be operative. For instance, by building a genome-wide miR-191 target set, Polioudakis et al. were able to identify and validate RPS6KA3 as a direct target of miR-191 [55]. MicroRNAs are a class of small non-coding RNAs that act as posttranscriptional gene regulators. miR-191 is abnormally expressed in over 20 types of cancer and in protean other diseases, e.g., Crohn's, diabetes-type 2, Alzheimer's, and pulmonary hypertension. By modulating important transcription factors, miR-191 regulates a variety of cellular processes: chromatin remodeling, cell cycle, differentiation, proliferation, migration, and apoptosis.

Other activities may also be relevant to perturbed RPS6KA3. For instance, knockdown of histone deacetylase 2 (HDAC2) induces RPS6KA3 repression and offers preclinical proof-of-concept for HDAC2 blockade in HCC [56].

\section{PTEN loss or alterations}

PTEN loss by immunohistochemistry can be seen in up to $53 \%$ of patients diagnosed with HCC [57]. PTEN mutation or deletion (both of which are mechanisms that lead to loss of PTEN expression) may be discerned in a smaller proportion of patients $(\sim 20$ to $30 \%)[58,59]$. Loss of PTEN activates the PI3k/Akt/mTor axis and may be druggable by PIK3CA, AKT or mTor inhibitors. A phase 3 trial of the mTor inhibitor everolimus demonstrated no survival benefit for patients with advanced HCC who had failed sorafenib; however, the participants were not selected by PTEN or other PI3K-related abnormalities. Further investigation with appropriate biomarker selection is warranted [60].

\section{Epigenetics, MicroRNA (miRNA), long non-coding RNA and HCC}

Aberrant epigenetic silencing of tumor suppressor genes by promoter DNA hyper-methylation and histone deacetylation plays an important role in carcinogenesis. The potential reversibility of these epigenetic abnormalities makes targeting them with drugs that modify chromatin an attractive therapeutic approach [61].

In hepatic carcinogenesis, studies have shown that alterations in epigenetics and miRNA correlate with the progression from precancerous lesions to $\operatorname{HCC}[61,62]$. miRNA are small ( 22 nucleotide) non-coding RNAs that regulate expression of diverse target genes [63]. In HCC, tumor suppressor genes may be epigenetically silenced by histone modifications, such as methylation of histone $\mathrm{H} 3$ lysine 9 (H3K9) and tri-methylation of H3K27, as well as 
DNA hyper-methylation of CpG island promoters and histone deacetylation [61, 62, 64, 65]. In addition, oncogenes that may normally be inactive because of specific suppressor miRNA may be activated if the miRNA is epigenetically silenced [63]. Restoring the expression of tumor suppressor miRNA or tumor suppressor genes by inhibitors of DNA methylation and histone deacetylase may therefore be a rational treatment approach for HCC.

Recently, long, non-coding RNAs have also been found to be differentially expressed in HCC and have been implicated in HCC pathogenesis [66]. Non-coding RNAs were once thought to be transcriptional "noise". However, accumulating investigations have shown these molecules to play significant regulatory roles. Long non-coding RNAs (over 200 nucleotides in length) are endogenous cellular RNA molecules that are incapable of being translated into proteins. They have a significant role in epigenetic regulation since they modulate gene expression by mechanisms including chromatin modification and genomic imprinting. In HCC, long, non-coding RNA have been implicated in initiation, progression, and metastasis. However, research on these molecules in this disease remains in its infancy, as does how to exploit them for therapeutic purposes.

\section{Angiogenesis and HCC}

$\mathrm{HCC}$ is a hypervascular malignancy mostly supplied by hepatic arteries; in contrast, in normal liver parenchyma, regenerative and dysplastic nodules are generally supplied by the portal vein [67]. On microscopic exam, HCC shows marked vascular anomalies, arteriogenesis and capillarization. Vascular endothelial growth factor (VEGF) and angiopoietins are important endothelium-specific growth factor families in HCC. Sorafenib is a multikinase suppressor that inhibits tumor cell growth and angiogenesis by inhibiting VEGF receptor. Sorafenib has been approved for treatment of HCC based on a randomized controlled trial that showed a $\sim 2.5$ month survival advantage, albeit with response rates less than $5 \%$.

\section{Immunotherapy in HCC}

Immunotherapeutics are very promising therapeutic tools in many advanced cancers, especially those that are virally induced. HCC is therefore an attractive candidate for immunotherapy. Recently, immune checkpoint inhibitors, such as ipilimumab (CTLA4 inhibitor) and nivolumab (PD-1 inhibitor), demonstrated survival benefits in multiple tumor types, including melanoma, non-small cell lung cancer, and renal cell carcinoma [64, 65, 68, 69]. Programmed cell death protein 1 (PD-1) and its ligandsprogrammed cell death 1 ligand 1 (PD-L1) and 2 (PDL2)-play important roles in regulating immune responses PD-L1 was expressed in $82 \%$ of HCC specimens [70]. PDL1 expression was higher in hepatitis B-positive patients than in those that were negative for this virus. A phase I/II study of nivolumab in patients with advanced HCC demonstrated a $19 \%$ response rate (including 5\% complete responses) [71, 72]. Importantly, some responses were durable. Of note, in many malignancies, the presence of $\mathrm{PD}-\mathrm{L} 1$ is associated with response to anti-PD-1/PD-L1 agents $(0-17 \%$ response rate in PD-L1-negative versus $36-100 \%$ response rate in PD-L1-positive patients) [73]. From a mechanistic perspective, it is of interest that PDL1 is induced in hepatocytes by viral infection [74].

Other immunotherapeutic approaches are also worth mentioning. Oncolytic viruses offer the promise of selective cancer treatment via direct and immune-mediated mechanisms. The premise of oncolytic viruses lies in their preferential infection of cancerous cells [75]. In HCC, several oncolytic viruses have been studied in Phase I and II protocols [75]. Results from a phase 1 clinical trial of intratumoral JX-594 in patients with refractory liver tumors demonstrated mechanistic proof-of-concept, safety, and antitumor efficacy for JX-594 replication and systemic dissemination to distant metastases [76]. Of note, three HCC patients had tumor marker response (between 56\% and 98\% reduction), and one participant had a confirmed radiographic partial response. In a Phase II dose-finding clinical trial, JX-594 was administered at two doses (lowdose $\left(10^{8} \mathrm{PFU}\right)$ and high-dose $\left(10^{9} \mathrm{PFU}\right)$ of JX-594). The study was terminated early as patients receiving higher doses of JX-954 showed a significant longer overall median survival (14.1 months in the high-dose group versus 6.7 months in the low-dose group) [77]. Additional viruses that are in clinical trials include adenoviruses such as ONYX-015 as well as a vesicular stomatitis virus, which encodes the human IFN- $\beta$ gene (VSV-hIFN- $\beta$ ) (NCT01628640) [78]. ONYX-015 was effective in killing cells and suppressing HCC cell proliferation both in vitro and in vivo. The cell killing was more prominent in cells possessing abnormal p53 [79].

Therapeutic regimens that counteract the immunosuppressive mechanisms have the potential to dramatically alter clinical outcomes of HCC. Currently, the multitargeted kinase inhibitor sorafenib, which improves survival by $2.3-2.8$ months, is the standard of care for patients with advanced HCC [15, 80, 81]. There is an urgent need for new, molecularly or immune-targeted agents that would improve clinical outcomes [81, 82]. Antibody-mediated blockade of PD-1 has demonstrated therapeutic benefit in the setting of refractory solid tumors, while inhibition of Tim-3 signaling in pre-clinical models helped to reestablish anti-tumor T cell activity [83, 84]. Immunotherapy affecting angiogenesis and/or the tumor vasculature portrays an effective modality based on the potential to generate longlived anti-vascular $\mathrm{T}$ cell responses. Pre-clinical data from Niethammer and coworkers indicated that an anti-VEGFR2 vaccine re-establishes an autoimmune response against self antigens and blocks tumor dissemination through a $\mathrm{T}$ cell- 
dependent process [85]. VCAM-1 also plays an important role in trapping activated $\mathrm{T}$ cells in the liver microvasculature, which modulates HBV- and HCV-related hepatic carcinogenesis and may provide unique treatment targets for HBV- and HCV-associated HCCs [86]. Lizuka et al. found up-regulation of $\mathrm{NK}$ cell-associated killer cell immunoglobulin-like receptors (KIRs) in $\mathrm{HCV}$-infected (and not HBV-infected) HCC patients [87]. Importantly immunotherapy needs to be tailored to individual patients based on the discrete etiologies for their HCCs [81].

\section{Conclusions}

\section{Perspective and future directions}

HCC is a difficult-to-treat and lethal malignancy. Chemotherapy did not prolong overall survival in HCC, and there is an unmet need to develop novel therapeutics for this illness. The emergence of genomic- and immune-based therapies is transforming treatment of many cancers and is beginning to be applied to HCC.

Of note, there are several genomic mutations that are common in HCC. The TERT promoter is mutated in approximately $60 \%$ to $90 \%$ of patients, and remains a challenge to target. Alterations in TP53 are seen in up to $40 \%$ of HCC patients. CTNNB1 is a negative regulator of the Wnt pathway, and often altered in HCC. FGF anomalies, as well as alterations in the cell cycle machinery and PTEN loss, are frequently observed. Some of these abnormalities may be pharmacologically tractable by approved agents or by specific inhibitors that are under development.

Novel immune checkpoint inhibitors are gaining momentum in other cancers such as melanoma and non-small cell lung cancer. In HCC, a phase II study with nivolumab in patients with Child-Pugh A HCC revealed encouraging results: $19 \%$ overall response rate and potential for durable response. The number of patients is small, and additional trials are in progress. Novel immune therapy, such as antiPD-L1 or other immune-targeted agents, has the potential to change the landscape of $\mathrm{HCC}$ treatment in the future.

Although systemic therapy in $\mathrm{HCC}$ has been disappointing in the past, we are at the dawn of new era. More studies that utilize genomic profiling and biomarker-matched molecularly targeted therapy as well as immunotherapy, and combinations of the above, are needed in order to improve the prognosis of patients suffering from HCC and advance the field.

\section{Acknowledgements}

Funded in part by the Joan and Irwin Jacobs Fund philanthropic fund and by National Cancer Institute grant P30 CA016672.

\section{Competing interests}

Dr. Kurzrock has research funding from Genentech, Merck Serono, Pfizer, Sequenom, Foundation Medicine, and Guardant, as well as consultant fees from X-Biotech and Actuate Therapeutics and an ownership interest in Novena, Inc. and Curematch Inc. The other authors have nothing to disclose.

\section{Authors' contributions}

GK and SI drafted the manuscript. RK checked manuscript and made crtical changes and contributions. All authors read and approved the final manuscript.

\section{Publisher's Note}

Springer Nature remains neutral with regard to jurisdictional claims in published maps and institutional affiliations.

\section{Author details}

'Department of Geriatrics, University of California, UC San Diego, 9500 Gilman Drive, \#9111, La Jolla, CA 92093-9111, USA. Department of Medicine, Division of Hematology/Oncology, and Center for Personalized Cancer Therapy, University of California, Moores Cancer Center, San Diego, USA. ${ }^{3}$ Tokyo Medical and Dental University, Tokyo, Japan. ${ }^{4}$ Kaiser Permanente Southern California, San Diego, USA.

Received: 9 June 2017 Accepted: 15 August 2017

Published online: 30 August 2017

\section{References}

1. Fielding L. Current imaging strategies of primary and secondary neoplasms of the liver. Semin Interv Radiol. 2006;23:3-12.

2. El-Serag HB, Rudolph KL. Hepatocellular carcinoma: epidemiology and molecular carcinogenesis. Gastroenterology. 2007;132:2557-76. United States

3. Zhou HB, Hu JY, Hu HP. Hepatitis B virus infection and intrahepatic cholangiocarcinoma. World J Gastroenterol. 2014;20:5721-9.

4. Sia D, Hoshida Y, Villanueva A, Roayaie S, Ferrer J, Tabak B, Peix J, Sole $M$, Tovar $V$, Alsinet $C$, et al. Integrative molecular analysis of intrahepatic cholangiocarcinoma reveals 2 classes that have different outcomes. Gastroenterology. 2013;144:829-40.

5. El-Serag HB, Davila JA. Is fibrolamellar carcinoma different from hepatocellular carcinoma? A US population-based study. Hepatology. 2004;39:798-803.

6. Bertino G, Demma S, Ardiri A, Proiti M, Mangia A, Gruttadauria S, Toro A, Di Carlo I, Malaguarnera G, Bertino N, Malaguarnera M. The immune system in Hepatocellular carcinoma and potential new immunotherapeutic strategies. Biomed Res Int. 2015;2015:731469.

7. Xie Y, Liu S, Zhao Y, Zhang L, Liu B, Guo Z. Precore/Core region mutations in hepatitis B virus DNA predict postoperative survival in Hepatocellular carcinoma. PLoS One. 2015;10:e0133393.

8. Della Corte C, Aghemo A, Colombo M. Individualized hepatocellular carcinoma risk: the challenges for designing successful chemoprevention strategies. World J Gastroenterol: WJG. 2013;19:1359-71.

9. Ward SC, Waxman S. Fibrolamellar carcinoma: a review with focus on genetics and comparison to other malignant primary liver tumors. Semin Liver Dis. 2011;31:61-70.

10. Andersen JB. Fibrolamellar Hepatocellular carcinoma: a rare but distinct type of liver cancer. Gastroenterology. 2015;148:707-10.

11. Buckley AF, Burgart $\sqcup$, Kakar S. Epidermal growth factor receptor expression and gene copy number in fibrolamellar hepatocellular carcinoma. Hum Pathol. 2006;37:410-4. United States

12. Deng GL, Zeng $\mathrm{S}$, Shen $\mathrm{H}$. Chemotherapy and target therapy for hepatocellular carcinoma: new advances and challenges. World J Hepatol. 2015;7:787-98.

13. Knudsen ES, Gopal P, Singal AG. The changing landscape of hepatocellular carcinoma: etiology, genetics, and therapy. Am J Pathol. 2014;184:574-83.

14. Cheng AL, Kang YK, Chen Z, Tsao CJ, Qin S, Kim JS, Luo R, Feng J, Ye S, Yang TS, et al. Efficacy and safety of sorafenib in patients in the Asia-Pacific region with advanced hepatocellular carcinoma: a phase III randomised, double-blind, placebo-controlled trial. Lancet Oncol. 2009;10:25-34.

15. Llovet JM, Ricci S, Mazzaferro V, Hilgard P, Gane E, Blanc JF, De Oliveira AC, Santoro A, Raoul JL, Forner A, et al. Sorafenib in advanced hepatocellular carcinoma. N Engl J Med. 2008;359:378-90.

16. Guan YS, He Q. Sorafenib: activity and clinical application in patients with hepatocellular carcinoma. Expert Opin Pharmacother. 2011;12:303-13.

17. Ehrlich SM, Liebl J, Ardelt MA, Lehr T, De Toni EN, Mayr D, Brandl L, Kirchner T, Zahler S, Gerbes AL, Vollmar AM. Targeting cyclin dependent kinase 5 in hepatocellular carcinoma - a novel therapeutic approach. J Hepatol. 2015; 63(1):102-13.

18. Schulze K, Imbeaud S, Letouze E, Alexandrov LB, Calderaro J, Rebouissou S, Couchy G, Meiller C, Shinde J, Soysouvanh F, et al. Exome sequencing of 
hepatocellular carcinomas identifies new mutational signatures and potential therapeutic targets. Nat Genet. 2015;47:505-11. United States

19. Villanueva A, Newell P, Chiang DY, Friedman SL, Llovet JM. Genomics and signaling pathways in hepatocellular carcinoma. Semin Liver Dis. 2007;27:55-76.

20. Guichard C, Amaddeo G, Imbeaud S, Ladeiro Y, Pelletier L, Maad IB, Calderaro J, Bioulac-Sage P, Letexier M, Degos F, et al. Integrated analysis of somatic mutations and focal copy-number changes identifies key genes and pathways in hepatocellular carcinoma. Nat Genet. 2012;44:694-8. United States

21. Takai A, Dang HT, Wang XW. Identification of drivers from cancer genome diversity in hepatocellular carcinoma. Int J Mol Sci. 2014;15:11142-60. Switzerland

22. Ahn SM, Jang SJ, Shim JH, Kim D, Hong SM, Sung CO, Baek D, Haq F, Ansari AA, Lee SY, et al. Genomic portrait of resectable hepatocellular carcinomas: implications of RB1 and FGF19 aberrations for patient stratification. Hepatology. 2014;60:1972-82.

23. Belinky F, Nativ N, Stelzer G, Zimmerman S, Iny Stein T, Safran M, Lancet D. PathCards: multi-source consolidation of human biological pathways. Database (Oxford). 2015;2015:bav006.

24. Delgado E, Okabe H, Preziosi M, Russell JO, Alvarado TF, Oertel M, NejakBowen KN, Zhang Y, Monga SP. Complete response of Ctnnb1-mutated tumours to beta-catenin suppression by locked nucleic acid antisense in a mouse hepatocarcinogenesis model. J Hepatol. 2015;62:380-7.

25. Lee HJ, Wang NX, Shi DL, Zheng JJ. Sulindac inhibits canonical Wnt signaling by blocking the PDZ domain of the protein Dishevelled. Angew Chem Int Ed Eng. 2009;48:6448-52.

26. Messersmith WA, Shapiro Gl, Cleary JM, Jimeno A, Dasari A, Huang B, Shaik MN, Cesari R, Zheng X, Reynolds JM, et al. A phase I, dose-finding study in patients with advanced solid malignancies of the oral gamma-secretase inhibitor PF-03084014. Clin Cancer Res. 2015;21:60-7.

27. Lachenmayer A, Alsinet C, Savic R, Cabellos L, Toffanin S, Hoshida Y, Villanueva A, Minguez B, Newell P, Tsai HW, et al. Wnt-pathway activation in two molecular classes of hepatocellular carcinoma and experimental modulation by sorafenib. Clin Cancer Res. 2012;18:4997-5007.

28. Shivaani K: Phase II trial of PF-03084014 in adults with desmoid tumors/ aggressive fibromatosis. J Clin Oncol. 2015 ASCO Annual Meeting 2015. doi:10. 1200/jco.2015.33.15_suppl.10563. 33, no. 15_suppl (May 2015) 10563-10563.

29. Li J, Quan H, Liu Q, Si Z, He Z, Qi H. Alterations of axis inhibition protein 1 (AXIN1) in hepatitis B virus-related hepatocellular carcinoma and overexpression of AXIN1 induces apoptosis in hepatocellular cancer cells. Oncol Res. 2013;20:281-8.

30. Satoh S, Daigo Y, Furukawa Y, Kato T, Miwa N, Nishiwaki T, Kawasoe T, Ishiguro H, Fujita M, Tokino T, et al. AXIN1 mutations in hepatocellular carcinomas, and growth suppression in cancer cells by virus-mediated transfer of AXIN1. Nat Genet. 2000;24:245-50.

31. Huang SM, Mishina YM, Liu S, Cheung A, Stegmeier F, Michaud GA, Charlat $O$, Wiellette $E$, Zhang Y, Wiessner S, et al. Tankyrase inhibition stabilizes axin and antagonizes Wnt signalling. Nature. 2009:461:614-20. England

32. Schwaederle M, Lazar V, Validire P, Hansson J, Lacroix L, Soria JC, Pawitan Y, Kurzrock R. VEGF-A expression correlates with TP53 mutations in non-small cell lung cancer: implications for Antiangiogenesis therapy. Cancer Res. 2015;75:1187-90.

33. Said R, Hong DS, Warneke CL, Lee JJ, Wheler JJ, Janku F, Naing A, Falchook GS, Fu S, Piha-Paul S, et al. P53 mutations in advanced cancers: clinical characteristics, outcomes, and correlation between progression-free survival and bevacizumab-containing therapy. Oncotarget. 2013;4:705-14.

34. Wheler J, Janku F, Naing A, Li Y, Stephen B, Zinner R, Subbiah V, Fu S, Karp D, Falchook GS, et al: TP53 alterations correlate with response to VEGFNEGFR inhibitors:implications for targeted therapeutics. Mol Cancer Ther 2016.

35. Janku F, Kaseb AO, Tsimberidou AM, Wolff RA, Kurzrock R. Identification of novel therapeutic targets in the PI3K/AKT/mTOR pathway in hepatocellular carcinoma using targeted next generation sequencing. Oncotarget. 2014;5: 3012-22. United States

36. Kogiso T, Nagahara H, Hashimoto E, Ariizumi S, Yamamoto M, Shiratori K. Efficient induction of apoptosis by wee1 kinase inhibition in hepatocellular carcinoma cells. PLoS One. 2014;9:e100495. United States

37. Fujimoto A, Totoki Y, Abe T, Boroevich KA, Hosoda F, Nguyen HH, Aoki M, Hosono N, Kubo M, Miya F, et al. Whole-genome sequencing of liver cancers identifies etiological influences on mutation patterns and recurrent mutations in chromatin regulators. Nat Genet. 2012;44:760-4. United States
38. Samartzis EP, Gutsche K, Dedes K, Fink D, Stucki M, Imesch P. Loss of ARID1A expression sensitizes cancer cells to PI3K- and AKT-inhibition. Oncotarget. 2014; 5:5295-303.

39. Zhao H, Wang J, Han Y, Huang Z, Ying J, Bi X, Zhao J, Fang Y, Zhou H, Zhou $J$, et al. ARID2: a new tumor suppressor gene in hepatocellular carcinoma. Oncotarget. 2011;2:886-91.

40. Toffanin S, Cornella H, Harrington A, Llovet JM. Next-generation sequencing: path for driver discovery in hepatocellular carcinoma. Gastroenterology. 2012;143:1391-3.

41. Llovet JM, Villanueva A, Lachenmayer A, Finn RS. Advances in targeted therapies for hepatocellular carcinoma in the genomic era. Nat Rev Clin Oncol. 2015;12:436.

42. Sawey ET, Chanrion M, Cai C, Wu G, Zhang J, Zender L, Zhao A, Busuttil RW, Yee $\mathrm{H}$, Stein $\mathrm{L}$, et al. Identification of a therapeutic strategy targeting amplified FGF19 in liver cancer by Oncogenomic screening. Cancer Cell. 2011;19:347-58.

43. Kudo M: Updated results from phase1/2 trial of Lenvatinib (E7080), a multitargeted tyrosine kinase inhibitor, and biomaker correlative analyses in patients with advanced hepatocellular carcinoma. 7th ILCA annual conference. Celsion sponsored symposium, abstract O-031; 2013.

44. Llovet JM, Decaens T, Raoul JL, Boucher E, Kudo M, Chang C, Kang YK, Assenat E, Lim HY, Boige V, et al. Brivanib in patients with advanced hepatocellular carcinoma who were intolerant to sorafenib or for whom sorafenib failed: results from the randomized phase III BRISK-PS study. J Clin Oncol. 2013;31:3509-16.

45. Cheng A-L. Phase II study of front-line dovitinib (TKI258) versus sorafenib in patients (pts) with advanced hepatocellular carcinoma (HCC). J Clin Oncol. 2015;33(suppl 3):237.

46. Nault JC, Villanueva A. Intratumor molecular and phenotypic diversity in hepatocellular carcinoma. Clin Cancer Res. 2015;21:1786-8. United States: 2015 American Association for Cancer Research

47. Bruix J, Han K-H, Gores G, Llovet JM, Mazzaferro V. Liver cancer: approaching a personalized care. J Hepatol. 2015;62:S144-56.

48. Nault JC, Mallet M, Pilati C, Calderaro J, Bioulac-Sage P, Laurent C, Laurent A, Cherqui D, Balabaud C, Zucman-Rossi J. High frequency of telomerase reverse-transcriptase promoter somatic mutations in hepatocellular carcinoma and preneoplastic lesions. Nat Commun. 2013;4:2218. England

49. Tahtouh R, Azzi AS, Alaaeddine N, Chamat S, Bouharoun-Tayoun H, Wardi L, Raad I, Sarkis R, Antoun NA, Hilal G. Telomerase inhibition decreases alphafetoprotein expression and secretion by hepatocellular carcinoma cell lines: in vitro and in vivo study. PLoS One. 2015;10:e0119512. United States

50. Greten TF, Forner A, Korangy F, N'Kontchou G, Barget N, Ayuso C, Ormandy LA, Manns MP, Beaugrand M, Bruix J. A phase II open label trial evaluating safety and efficacy of a telomerase peptide vaccination in patients with advanced hepatocellular carcinoma. BMC Cancer. 2010;10:209.

51. Ruden M, Puri N. Novel anticancer therapeutics targeting telomerase. Cancer Treat Rev. 2013;39:444-56.

52. Cook BD, Dynek JN, Chang W, Shostak G, Smith S. Role for the related poly(ADP-ribose) polymerases tankyrase 1 and 2 at human telomeres. Mol Cell Biol. 2002;22:332-42.

53. Beneke S, Cohausz O, Malanga M, Boukamp P, Althaus F, Burkle A. Rapid regulation of telomere length is mediated by poly(ADP-ribose) polymerase1. Nucleic Acids Res. 2008;36:6309-17.

54. Zhang Y, Qiu Z, Wei L, Tang R, Lian B, Zhao Y, He X, Xie L. Integrated analysis of mutation data from various sources identifies key genes and signaling pathways in hepatocellular carcinoma. PLoS One. 2014;9:e100854.

55. Polioudakis D, Abell NS, lyer VR. MiR-191 regulates primary human fibroblast proliferation and directly targets multiple Oncogenes. PLoS One. 2015;10: e0126535.

56. Lee YH, Seo D, Choi K, Andersen JB, Won MA, Kitade M, Gomez-Quiroz LE, Judge AD, Marquardt JU, Raggi C, et al. Antitumor effects in hepatocarcinoma of isoform-selective inhibition of HDAC2. Cancer Res. 2014;74:4752-61.

57. Subbiah IM, Falchook GS, Kaseb AO, Hess KR, Tsimberidou AM, Fu S, Subbiah V, Hong DS, Naing A, Piha-Paul SA, et al. Exploring response signals and targets in aggressive unresectable hepatocellular carcinoma: an analysis of targeted therapy phase 1 trials. Oncotarget. 2015;6(29): 28453.

58. Hu TH, Huang CC, Lin PR, Chang HW, Ger LP, Lin YW, Changchien CS, Lee $\mathrm{CM}$, Tai MH. Expression and prognostic role of tumor suppressor gene PTEN/MMAC1/TEP1 in hepatocellular carcinoma. Cancer. 2003:97:1929-40. 
59. Kawamura N, Nagai H, Bando K, Koyama M, Matsumoto S, Tajiri T, Onda M, Fujimoto J, Ueki T, Konishi N, et al. PTEN/MMAC1 mutations in hepatocellular carcinomas: somatic inactivation of both alleles in tumors. Jpn J Cancer Res. 1999:90:413-8.

60. Zhu AX, Kudo M, Assenat E, Cattan S, Kang YK, Lim HY, Poon RT, Blanc JF, Vogel $\mathrm{A}$, Chen $\mathrm{CL}$, et al. Effect of everolimus on survival in advanced hepatocellular carcinoma after failure of sorafenib: the EVOLVErandomized clinical trial. JAMA. 2014;312:57-67.

61. Hellebrekers DM, Griffioen AW, van Engeland M. Dual targeting of epigenetic therapy in cancer. Biochim Biophys Acta. 2007;1775:76-91.

62. Tischoff I, Tannapfe A. DNA methylation in hepatocellular carcinoma. World J Gastroenterol. 2008;14:1741-8.

63. Saito $Y$, Hibino $S$, Saito $H$. Alterations of epigenetics and microRNA in hepatocellular carcinoma. Hepatol Res. 2014;44:31-42.

64. Hodi FS, O'Day SJ, McDermott DF, Weber RW, Sosman JA, Haanen JB, Gonzalez R, Robert C, Schadendorf D, Hassel JC, et al. Improved survival with ipilimumab in patients with metastatic melanoma. N Engl J Med. 2010; 363:711-23.

65. Brahmer J, Reckamp KL, Baas P, Crino L, Eberhardt WE, Poddubskaya E, Antonia S, Pluzanski A, Vokes EE, Holgado E, et al. Nivolumab versus Docetaxel in advanced Squamous-cell non-small-cell lung cancer. N Engl J Med. 2015;373:123-35.

66. Liu YR, Tang RX, Huang WT, Ren FH, He RQ, Yang LH, Luo DZ, Dang YW, Chen G. Long noncoding RNAs in hepatocellular carcinoma: novel insights into their mechanism. World J Hepatol. 2015;7:2781-91.

67. Muto J, Shirabe K, Sugimachi K, Maehara Y. Review of angiogenesis in hepatocellular carcinoma. Hepatol Res. 2015;45:1-9.

68. Borghaei H, Paz-Ares L, Horn L, Spigel DR, Steins M, Ready NE, Chow LQ Vokes EE, Felip E, Holgado E, et al. Nivolumab versus Docetaxel in advanced Nonsquamous non-small-cell lung cancer. N Engl J Med. 2015;373:1627-39.

69. Motzer RJ, Escudier B, McDermott DF, George S, Hammers HJ, Srinivas S, Tykodi SS, Sosman JA, Procopio G, Plimack ER, et al. Nivolumab versus Everolimus in advanced renal-cell carcinoma. N Engl J Med. 2015;373:1803-13.

70. Mody, Kabir, et al. "PD-1/PD-L1 expression and molecular associations in HPB malignancies." ASCO Annual Meeting Proceedings2016 34 4_suppl: 289.

71. Kan G, Dong W. The expression of PD-L1 APE1 and P53 in hepatocellular carcinoma and its relationship to clinical pathology. Eur Rev Med Pharmacol Sci. 2015;19:3063-71.

72. El-Khoueiry A: Phase I/II safety and antitumor activity of nivolumab in patients with advanced hepatocellular carcinoma (HCC): CA209-040jco. 2015.33.18_suppl.Iba101.

73. Patel SP, Kurzrock R. PD-L1 expression as a predictive biomarker in cancer immunotherapy. Mol Cancer Ther. 2015;14:847-56.

74. Muhlbauer M, Fleck M, Schutz C, Weiss T, Froh M, Blank C, Scholmerich J, Hellerbrand C. PD-L1 is induced in hepatocytes by viral infection and by interferon-alpha and -gamma and mediates T cell apoptosis. J Hepatol. 2006:45:520-8.

75. Jebar AH, Errington-Mais F, Vile RG, Selby PJ, Melcher AA, Griffin S. Progress in clinical oncolytic virus-based therapy for hepatocellular carcinoma. J Gen Virol. 2015;96:1533-50.

76. Park BH, Hwang T, Liu TC, Sze DY, Kim JS, Kwon HC, Oh SY, Han SY, Yoon $\mathrm{JH}$, Hong SH, et al. Use of a targeted oncolytic poxvirus, JX-594, in patients with refractory primary or metastatic liver cancer: a phase I trial. Lancet Oncol. 2008;9:533-42.

77. Heo J, Reid T, Ruo L, Breitbach CJ, Rose S, Bloomston M, Cho M, Lim HY, Chung HC, Kim CW, et al. Randomized dose-finding clinical trial of oncolytic immunotherapeutic vaccinia JX-594 in liver cancer. Nat Med. 2013;19:329-36.

78. Waidmann O, Trojan J. Novel drugs in clinical development for hepatocellular carcinoma. Expert Opin Investig Drugs. 2015;24:1075-82.

79. Habib NA, Mitry RR, Sarraf CE, Jiao LR, Havlik R, Nicholls J, Jensen SL. Assessment of growth inhibition and morphological changes in in vitro and in vivo hepatocellular carcinoma models post treatment with dl1520 adenovirus. Cancer Gene Ther. 2002;9:414-20.

80. Siegel AB, Olsen SK, Magun A, Brown RS Jr. Sorafenib: where do we go from here? Hepatology. 2010;52:360-9.

81. Pardee AD, Butterfield LH. Immunotherapy of hepatocellular carcinoma: unique challenges and clinical opportunities. Oncoimmunology. 2012;1:48-55.

82. Mizukoshi E, Nakamoto Y, Arai K, Yamashita T, Sakai A, Sakai Y, Kagaya T, Honda M, Kaneko S. Comparative analysis of various tumor-associated antigen-specific t-cell responses in patients with hepatocellular carcinoma. Hepatology. 2011;53:1206-16.
83. Brahmer JR, Drake CG, Wollner I, Powderly JD, Picus J, Sharfman WH, Stankevich E, Pons A, Salay TM, McMiller TL, et al. Phase I study of singleagent anti-programmed death-1 (MDX-1106) in refractory solid tumors: safety, clinical activity, pharmacodynamics, and immunologic correlates. J Clin Oncol. 2010;28:3167-75.

84. Sakuishi K, Apetoh L, Sullivan JM, Blazar BR, Kuchroo VK, Anderson AC. Targeting Tim-3 and PD-1 pathways to reverse T cell exhaustion and restore anti-tumor immunity. J Exp Med. 2010;207:2187-94.

85. Niethammer AG, Xiang R, Becker JC, Wodrich H, Pertl U, Karsten G, Eliceiri BP, Reisfeld RA. A DNA vaccine against VEGF receptor 2 prevents effective angiogenesis and inhibits tumor growth. Nat Med. 2002;8:1369-75.

86. John B, Crispe IN. Passive and active mechanisms trap activated CD8+ T cells in the liver. J Immunol. 2004;172:5222-9.

87. lizuka N, Oka M, Yamada-Okabe H, Mori N, Tamesa T, Okada T, Takemoto N, Tangoku A, Hamada K, Nakayama H, et al. Comparison of gene expression profiles between hepatitis B virus- and hepatitis C virus-infected hepatocellular carcinoma by oligonucleotide microarray data on the basis of a supervised learning method. Cancer Res. 2002;62:3939-44.

88. Walther Z, Jain D. Molecular pathology of hepatic neoplasms: classification and clinical significance. Pathol Res Int. 2011;2011:403929.

89. Bioulac-Sage P, Laumonier H, Rullier A, Cubel G, Laurent C, Zucman-Rossi J, Balabaud C. Over-expression of glutamine synthetase in focal nodular hyperplasia: a novel easy diagnostic tool in surgical pathology. Liver Int. 2009;29:459-65.

90. Zheng S, Cummings OW, Saxena R, Zhang S, Wang M, Williamson SR, Cheng M, Lopez-Beltran A, Montironi R, Hodges KB, Cheng L. Clonality and TP53 mutation analysis of focal nodular hyperplasia of the liver. Am J Clin Pathol. 2010;134:65-70.

91. Chen YW, Jeng YM, Yeh SH, Chen PJ. P53 gene and Wnt signaling in benign neoplasms: beta-catenin mutations in hepatic adenoma but not in focal nodular hyperplasia. Hepatology. 2002;36:927-35.

92. Bioulac-Sage P, Rebouissou S, Sa Cunha A, Jeannot E, Lepreux S, Blanc JF, Blanche H, Le Bail B, Saric J, Laurent-Puig P, et al. Clinical, morphologic, and molecular features defining so-called telangiectatic focal nodular hyperplasias of the liver. Gastroenterology. 2005:128:1211-8.

93. Bluteau O, Jeannot E, Bioulac-Sage P, Marques JM, Blanc JF, Bui H, Beaudoin JC, Franco D, Balabaud C, Laurent-Puig P, Zucman-Rossi J. Biallelic inactivation of TCF1 in hepatic adenomas. Nat Genet. 2002;32: 312-5.

94. Zucman-Rossi J, Jeannot E, Nhieu JT, Scoazec JY, Guettier C, Rebouissou S, Bacq Y, Leteurtre E, Paradis V, Michalak S, et al. Genotype-phenotype correlation in hepatocellular adenoma: new classification and relationship with HCC. Hepatology. 2006;43:515-24.

95. Bioulac-Sage P, Rebouissou S, Thomas C, Blanc JF, Saric J, Sa Cunha A, Rullier A, Cubel G, Couchy G, Imbeaud S, et al. Hepatocellular adenoma subtype classification using molecular markers and immunohistochemistry. Hepatology. 2007:46:740-8.

96. Pathologic diagnosis of early hepatocellular carcinoma. A report of the international consensus group for hepatocellular neoplasia. Hepatology. 2009:49:658-64

97. Nault JC, Calderaro J, Di Tommaso L, Balabaud C, Zafrani ES, Bioulac-Sage P, Roncalli M, Zucman-Rossi J. Telomerase reverse transcriptase promoter mutation is an early somatic genetic alteration in the transformation of premalignant nodules in hepatocellular carcinoma on cirrhosis. Hepatology. 2014;60:1983-92.

98. Park YN. Update on precursor and early lesions of hepatocellular carcinomas. Arch Pathol Lab Med. 2011;135:704-15.

99. Paradis V, Bieche I, Dargere D, Laurendeau I, Laurent C, Bioulac Sage P, Degott C, Belghiti J, Vidaud M, Bedossa P. Molecular profiling of hepatocellular carcinomas (HCC) using a large-scale real-time RT-PCR approach: determination of a molecular diagnostic index. Am J Pathol. 2003;163:733-41.

100. Nam SW, Park JY, Ramasamy A, Shevade S, Islam A, Long PM, Park CK, Park SE, Kim SY, Lee SH, et al. Molecular changes from dysplastic nodule to hepatocellular carcinoma through gene expression profiling. Hepatology. 2005:42:809-18.

101. Llovet JM, Chen Y, Wurmbach E, Roayaie S, Fiel MI, Schwartz M, Thung SN, Khitrov G, Zhang W, Villanueva A, et al. A molecular signature to discriminate dysplastic nodules from early hepatocellular carcinoma in HCV cirrhosis. Gastroenterology. 2006;131:1758-67. 
102. Chuma M, Sakamoto M, Yamazaki K, Ohta T, Ohki M, Asaka M, Hirohashi S. Expression profiling in multistage hepatocarcinogenesis: identification of HSP70 as a molecular marker of early hepatocellular carcinoma. Hepatology. 2003:37:198-207.

103. Kaposi-Novak P, Libbrecht L, Woo HG, Lee YH, Sears NC, Coulouarn C, Conner EA, Factor VM, Roskams T, Thorgeirsson SS. Central role of c-Myc during malignant conversion in human hepatocarcinogenesis. Cancer Res. 2009;69:2775-82.

104. Yamauchi. The glypican 3 oncofetal protein is a promising diagnostic marker for hepatocellular carcinoma. Watanabe A ed. Mod Pathol. 2005;18:1591-8.

105. Di Tommaso L, Franchi G, Park YN, Fiamengo B, Destro A, Morenghi E, Montorsi M, Torzilli G, Tommasini M, Terracciano $L$, et al. Diagnostic value of HSP70, glypican 3, and glutamine synthetase in hepatocellular nodules in cirrhosis. Hepatology. 2007:45:725-34.

106. Christa L, Simon MT, Flinois JP, Gebhardt R, Brechot C, Lasserre C. Overexpression of glutamine synthetase in human primary liver cancer. Gastroenterology. 1994;106:1312-20.

107. Di Tommaso L, Destro A, Seok JY, Balladore E, Terracciano L, Sangiovanni A, lavarone M, Colombo M, Jang JJ, Yu E, et al. The application of markers (HSP70 GPC3 and GS) in liver biopsies is useful for detection of hepatocellular carcinoma. J Hepatol. 2009;50:746-54.

108. Laurent-Puig P, Legoix P, Bluteau O, Belghiti J, Franco D, Binot F, Monges G, Thomas G, Bioulac-Sage P, Zucman-Rossi J. Genetic alterations associated with hepatocellular carcinomas define distinct pathways of hepatocarcinogenesis. Gastroenterology. 2001;120:1763-73.

109. Gouas D, Shi H, Hainaut P. The aflatoxin-induced TP53 mutation at codon 249 (R249S): biomarker of exposure, early detection and target for therapy. Cancer Lett. 2009;286:29-37.

110. Koh CM, Khattar E, Leow SC, Liu CY, Muller J, Ang WX, Li Y, Franzoso G, Li S, Guccione E, Tergaonkar V. Telomerase regulates MYC-driven oncogenesis independent of its reverse transcriptase activity. J Clin Invest. 2015;125:2109-22.

111. Wong CH, Wong CS, Chan SL. Targeting angiogenic genes as a therapeutic approach for hepatocellular carcinoma. Curr Gene Ther. 2015;15:97-108. Netherlands

112. Clinicaltrials.gov. In. Bethesda MNLoM: Clinicaltrials.gov. In. Bethesda, MD: National Library of Medicine.

113. Boon EM, Keller JJ, Wormhoudt TA, Giardiello FM, Offerhaus GJ, van der Neut R, Pals ST. Sulindac targets nuclear beta-catenin accumulation and Wnt signalling in adenomas of patients with familial adenomatous polyposis and in human colorectal cancer cell lines. Br J Cancer. 2004;90:224-9.

114. Ho HK, Yeo AH, Kang TS, Chua BT. Current strategies for inhibiting FGFR activities in clinical applications: opportunities, challenges and toxicological considerations. Drug Discov Today. 2014;19:51-62.

\section{Submit your next manuscript to BioMed Central and we will help you at every step:}

- We accept pre-submission inquiries

- Our selector tool helps you to find the most relevant journal

- We provide round the clock customer support

- Convenient online submission

- Thorough peer review

- Inclusion in PubMed and all major indexing services

- Maximum visibility for your research

Submit your manuscript at www.biomedcentral.com/submit 